\title{
ABILITY OF SULFATE-REDUCING BACTERIA TO UTILIZE POLYMER AND RUBBER MATERIALS
}

\author{
D.R. Abdulina ${ }^{1}$, A.I. Chuenko ${ }^{1}$, A.S. Topchiy ${ }^{2}$, \\ G.E. Kopteva ${ }^{I}$, Zh.P. Kopteva ${ }^{1}$ \\ ${ }^{1}$ Zabolotny Institute of Microbiology and Virology, NAS of Ukraine, \\ 154 Acad. Zabolotny Str., Kyiv, 03143, Ukraine \\ ${ }^{2}$ Taras Shevchenko National University of Kyiv, \\ 2 Acad. Glushkova ave., Kyiv, 02000, Ukraine \\ e-mail:adara@ukr.net
}

\begin{abstract}
Polymer materials are an integral part of our lives, but their use is a global environmental problem. Despite this, the development of modern approaches to the utilization of used polymer and rubber materials is currently relevant, including the using of anaerobic microbial destruction of polymers by sulfatereducing bacteria. The aim of the work. To study the ability of sulfate-reducing bacteria to utilize rubber and polymer materials such as solid rubber, ethylene vinyl acetate and foamed polyethylene. Methods. Microbiological (cultivation of sulfate-reducing bacteria, method of serial dilutions), biochemical (Lowry method, measurement of enzymatic activity), physical and chemical (gravimetry, iodometry, potentiometry, gas chromatography-mass spectrometry). Results. It was shown that in the presence of the studied materials as the sole sources of carbon, the amount of sulfate-reducing bacteria increased by 2-3 orders compared to the control without adding the materials. On the $90^{\text {th }}$ day of the experiment the destruction coefficients of the studied materials were low and reached $K_{D}=0.21-2.88 \%$. In the cultivation medium with the introduced studied materials, the metabolic and enzymatic activity of sulfate-reducing bacteria are changed, in particular, the production of hydrogen sulfide in the presence of ethylene vinyl acetate and foamed polyethylene increased by 0.8-3 times, and rubber-decreased by 1.2-3.5 times. The catalase activity of the studied bacterial cultures was decreased by 1.4-3.4 times compared to the control without adding of materials. During the exposure period with adding the materials, the lipase activity of bacterial cultures decreased and in some cases almost disappeared. The introduction of materials led to increasing of the short-chain fatty acids synthesis by Desulfovibrio desulfuricans DSM642 and D. vulgaris DSM644 strains, while, on the contrary, Desulfovibrio sp. 10 strain showed the decreasing in acid production. The introduction of rubber only in D. vulgaris DSM644 culture leads to the increasing of acetic and propanoic acids synthesis by $59 \%$ and $49.5 \%$, respectively, compared to the control without the introduction of the studied materials. The synthesis of acetic acid in the presence of foamed polyethylene and ethylene vinyl acetate in the cultural liquid of sulfate-reducing bacteria increased by $46.2-419.5 \%$ and $69.8-92.6 \%$, and propane - by 23.1-46.2\% and 71.9-159.0\%, respectively. Conclusions. The presence in cultivation media of rubber, foamed polyethylene and ethylene vinyl acetate as a sole carbon sources led to the changes in enzymatic activity (catalase and lipase), the intensification of hydrogen sulfide synthesis by bacteria was observed as well as acetic, propanoic and butanoic acids synthesis increased. This indicates the potential of sulfate-reducing bacteria to utilize the studied materials via acid formation.
\end{abstract}

Keywords: sulfate-reducing bacteria, biodegradation, destruction coefficient, catalase, lipase activity, short-chain fatty acids, polymer and rubber materials.

Annually according to the data of Ministry of regional development, construction and housing and communal services, about 150 thousand tons of rubber waste (mainly in the form of used tires, insulation and household waste) falls into Ukrainian landfills. Waste of other polymer and textile materials (polyurethane, polyvinyl chloride, polyethylene and polystyrene) they are about 50 thousand tons (https://www.minregion.gov.ua/).
Recently, the area of landfills is approximately $7 \%$ of the Ukraine's territory, which exceeds the area of national parks (https://ecomapa.gov.ua/). The rapid accumulation of solid waste adversely affects the environment and creates a number of economic and social problems [1]. The means with the use of microorganisms (i.e. biodegradation) for the decomposition (neutralization) of polymer and rubber materials can prevent environmental damage 
and therefore are promising in the utilization of xenobiotic compounds [2]. Currently, microscopic fungi of Pycnoporus, Ceriporiopsis, Trichoderma, Fusarium, Aspergillus, Cladosporium, Penicillum and Rhizopus genera as well as bacteria of Bacillus, Corynebacterium, Staphylococcus, Streptococcus, Shigella, Yarrowia, Rhodococcus, Gordonia, Acinetobacter Escherichia, Klebsiella and Enterobacter genera are considered as promising biological degradation agents [3-7]. Also there are hydrocarbon-oxidizing bacteria Pseudomonas pseudoalcaligenes 109, Rhodococcus erythropolis 102, Bacillus subtilis 138 that can utilize components of polymer coatings of pipelines [8].

The process of microbial destruction of compounds can occur in aerobic and anaerobic pathways. The products of complete aerobic oxidation are carbon dioxide and water, with a simultaneous increase in the mass of microorganisms [9]. As a result of complete anaerobic degradation of polymers organic acids, methane, carbon dioxide and water are produced, moreover, nitrogen gas $\left(\mathrm{N}_{2}\right)$, hydrogen sulfide $\left(\mathrm{H}_{2} \mathrm{~S}\right)$ etc. can be a side-products of anaerobic respiration. It is known from the literature that under favorable conditions, the decomposition of rubber and various plastics by hydrolytic and redox enzymes of microorganisms can significantly reduce the solid waste's mass of these materials and also can help to obtain valuable chemical compounds. Today, there is a possibility of biodegradation of a number of xenobiotic compounds such as polypropylene, polycarbonates, polyamides, etc. [10]. In particular, scientists from Japan recently described a newly isolated Ideonella sakaiensis 201-F6 bacteria, which can degrade polyethylene terephthalate plastic (PET). It was found that the key PET-ase enzyme in I. sakaiensis 201-F6 is secreted during the biodegradation process [11].

The microbiological approach to polymer waste disposal is relevant, which is based on the step-bystep treatment of rubber and polymer waste with culture liquid of microorganisms that produce hydrolytic and redox enzymes, which makes it possible to effectively carry out the process of biodegradation in aerobic and anaerobic conditions. Previously, we showed that aerobic hydrocarbonsoxidizing bacteria P. pseudoalcaligenes 109, R. erythropolis 102, B. subtilis 138 affected polymer and rubber materials by synthesizing hydrolytic and redox enzymes [12]. The ability of anaerobic sulfate-reducing bacteria (SRB) to degrade polymer compounds under anaerobic conditions has been studied only in the last two decades [13] and there is still a lack of data. Taking into account the above, the aim of the work was to investigate the ability of anaerobic SRB to recycle polymer and rubber materials.

\section{Materials and methods}

Objects of study were SRB strains Desulfovibrio sp. 10 (UCM B-11503), Desulfovibrio desulfuricans DSM642 (UCM B-11501), D. vulgaris DSM644 (UCM B-1150) from Ukrainian Collection of Microorganisms (UCM) of the D.K. Zabolotny Institute of Microbiology and Virology of the NAS of Ukraine.

Materials. Polymer and rubber materials such as foamed polyethylene (fPE, manufacturer - SANPOL group of companies), ethylene vinyl acetate (EVA, manufacturer - IZOLON) and solid rubber (manufacturer - Gnivansky tire repair plant, Ukraine) were used in the work.

Study design. The experiments were performed at $28 \pm 2{ }^{\circ} \mathrm{C}$ in the Postgate " $\mathrm{B}$ " liquid medium, in which studied materials were the sole source of carbon. Samples with sizes of 20x20x2 mm were weighed on an analytical balances (ANG-200, AXIS), sterilized in $70 \%$ ethanol solution (15$30 \mathrm{~min}$ ) and with UV exposure (wavelength $256 \mathrm{~nm}, 15 \mathrm{~min}$ ) on each side. Prepared samples were introduced into a sterile Postgate "B" medium, inoculated with bacterial culture of one of the above-mentioned SRB strains in amount of $5 \% \mathrm{vol} / \mathrm{vol}$. The bacterial titers in the cultural liquid were determined by method of serial dilutions and amounts were calculated using the MacCrady table. The sterile Postgate "B" medium without lactate with the introduction of polymer samples as well as medium inoculated with SRB without the materials adding were used as a control. The duration of the exposure were 14, 30, 90 days. After a certain period of exposure, the vials were removed from the experiment for analysis. Experimental samples of materials after exposure were treated with a $20 \%$ solution of citric acid (15-20 min) to remove insoluble sulfides, then washed in a $1 \mathrm{n}$ phosphatesalt buffer $\left(5 \mathrm{ml}\right.$ of $11.876 \mathrm{~g} \mathrm{Na}_{2} \mathrm{HPO}_{4}$ × $2 \mathrm{H}_{2} \mathrm{O}$ solution and $95.0 \mathrm{ml}$ of $0.78 \mathrm{~g} \mathrm{KH}_{2} \mathrm{PO}_{4}$ solution, $\mathrm{pH}=7.6$ ), dried at room temperature and weighed on analytical balances.

Enzymatic activity measurement. The cultural liquid was centrifuged at $8000 \mathrm{rpm}(2000 \mathrm{~g})$ (20 min) at Eppendorf centrifuge (Germany) with a 5810R rotor for separation of bacterial biomass. Total protein was determined in the supernatant using the standard Lowry method, lipolytic activity was determined by spectrophotometric method on 
the KFK-3 spectrophotometer (Russia) in reaction with $n$-nitrophenyl palmitate [14]. Catalase activity was determined using $0.03 \%$ hydrogen peroxide, which formed a stable colored complex with a $4 \%$ solution of molybdenum orthophosphate [15]. The specific activity of the studied enzymes was expressed in unit per mg of protein.

Biodegradation of materials was evaluated visually, at a magnification of 14 times on the MBS10 device (USSR) with photo documentation of morphological changes of the samples. According to the change in the sample masses, the destruction coefficients were calculated using the formula [16]:

$$
\mathrm{K}_{\mathrm{D}}=\left(\frac{\mathrm{m} 0}{\mathrm{~m} 1}-1\right) \times 100 \%
$$

where $\mathrm{m} 0$ is the mass of the sample before the start of the experiment; $\mathrm{m} 1$ is the mass of the sample at the corresponding determination point.

Physical and chemical measurements. The $\mathrm{pH}$ of the cultural liquid was determined using potentiometric method on the I-160MI device (Russia). The accumulation of hydrogen sulphide by SRB was determined in the cultural liquid using the iodometric method.

Determination of short-chain fatty acids. The content of short-chain fatty acids in the culture liquid supernatant was studied by gas chromatography-mass spectrometry using an Agilent 6890N/5973 inert device (Agilent Technologies, USA), HP-INNOWax capillary column $(30 \mathrm{~m} \times 0.25 \mathrm{~mm} \times 0.25 \mathrm{microns}) \quad(\mathrm{J} \& \mathrm{~W}$ Scientific, USA). The analysis was performed with a temperature gradient at $20^{\circ} \mathrm{C} / \mathrm{min}$ from 40 to $250{ }^{\circ} \mathrm{C}$, the gas-carrier was helium, and the flow rate through the column was $1 \mathrm{ml} / \mathrm{min}$. The injection volume (sample) was $0.2 \mu 1$. As an internal standard, isovaleric (3-methylbutanoic) acid was used in the final concentration of $40 \mu \mathrm{g} / \mathrm{ml}$. Identification of short-chain organic acids was performed using NIST02 mass spectrum libraries databases and standard organic acid solutions (Sigma-Aldrich, USA) [17].

Statistical processing of the results. The experiments were repeated three times. The data was expressed as $(M \pm m, p \leq 0.05)$. The analysis of research results was performed using the MS Excel 2010 software.

Results. Previously, we studied the collection hydrocarbons-oxidizing bacteria (HOB) $P$. pseudoalcaligenes 109, R. erythropolis 102 and B. subtilis 138 influence on the materials [12]. These bacteria are aerobic polyreductants with capacity to reduce trivalent iron, nitrates, and able to oxidize hydrocarbons [8]. In the presence of rubber, polyethylene and ethylene vinyl acetate, the changes in the enzymatic activity of the above-mentioned bacteria, as well as in the polymer materials component composition were observed. In contrast to the HOB strains, SRB are anaerobic bacteria that will distinguish their effect on the picked polymer materials. As a result of the conducted study, it was shown that during all the exposure period in Postgate "B" medium with the rubber, fPE and EVA as the sole carbon source the increase in the amount of SRB was noted. After 30-90 days of exposure in all the variants of experiment, as well as in the control ones without adding the studied materials, the SRB titer was maximum $1.0 \times 10^{10}$ cells $/ \mathrm{ml}$ (Table 1 ). Therefore, the presence of the studied materials did not have an inhibitory effect on the growth of the bacteria, so, they were able to use rubber, fPE and EVA as a carbon source.

The morphological changes in the surfaces of the studied materials due to the influence of SRB were evaluated (Fig. 1).

Visual evaluation of the material samples after 14th days of exposure showed that no noticeable changes in the polymer surface structure were observed. On the $30^{\text {th }}$ day of the exposure, minor white spots were observed on the rubber samples, the fPE and EVA samples had pronounced changes, which were manifested in their partial discoloration, deformations visible to the naked eye, the appearance of black spots and rusty colored sediment. The most notable changes in the studied materials were observed on the $90^{\text {th }}$ day of exposure.

An indicator of material degradation was the decrease in the mass of polymer samples during cultivation with bacteria. The destruction coefficient was calculated (Table 2).

After exposure of the materials in the control sterile Postgate " $\mathrm{B}$ " medium, no change in the mass of the rubber samples was observed $\left(\mathrm{K}_{\mathrm{D}}=0\right)$. In experimental variants inoculated with cultures of SRB under the influence of D. vulgaris DSM644 and Desulfovibrio sp. 10 strains on the $90^{\text {th }}$ day of exposure $\mathrm{K}_{\mathrm{D}}$ for rubber were $1.2 \%$ and $2.33 \%$, respectively. While $\mathrm{K}_{\mathrm{D}}$ for $\mathrm{PPE}$ varied from 0.57 to $2.88 \%$ during the exposure period, and did not exceed control values. After 90th days of cultivation of fPE and EVA in the control samples, $\mathrm{K}_{\mathrm{D}}$ was 2.99 and $1.17 \%$, and under the action of SRB cultures, $\mathrm{K}_{\mathrm{D}}=0.21-0.57 \%$. No significant changes were observed in the mass of polymer samples under the action of bacteria and the 
A

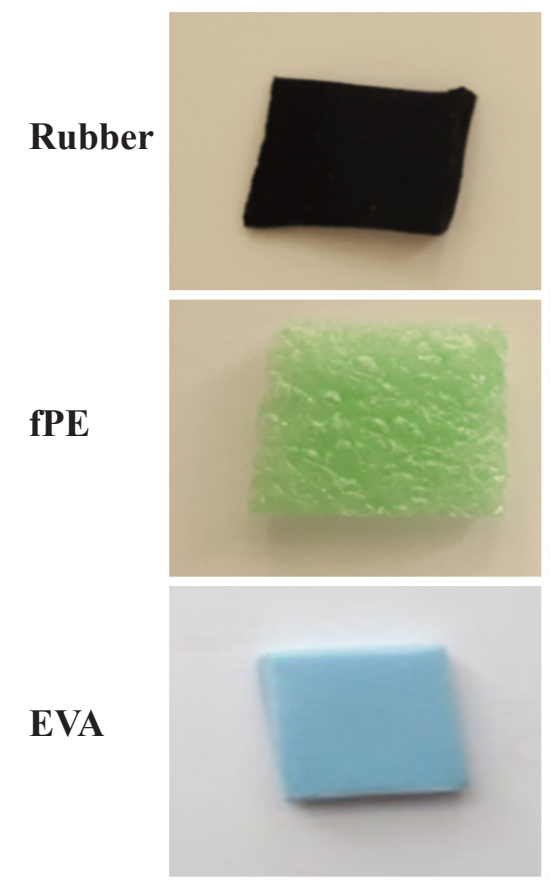

B

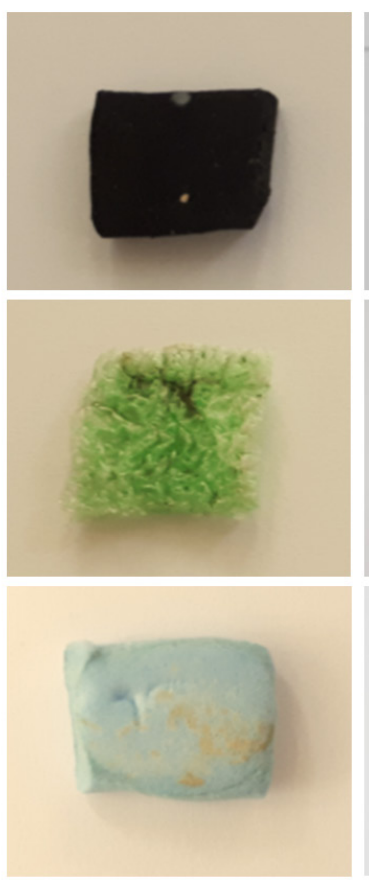

C
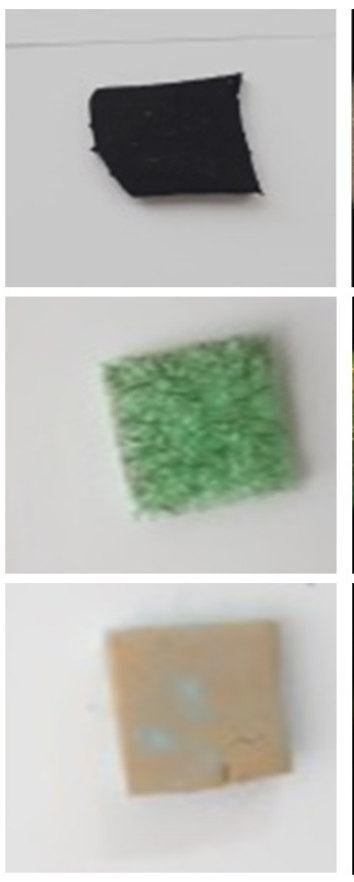

D
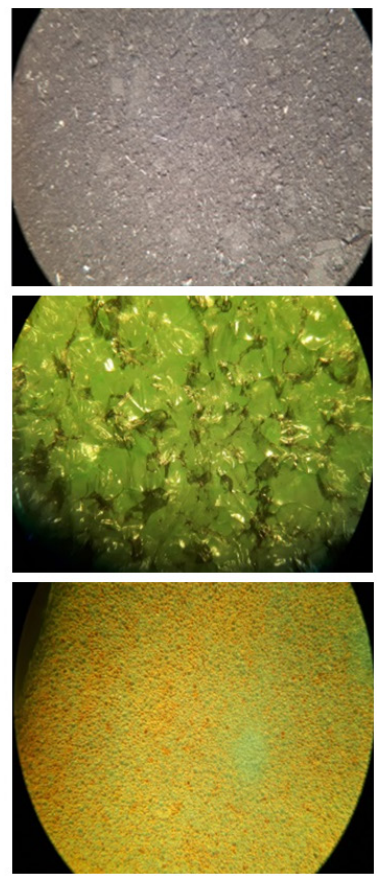

F i g. 1. The appearance of studied materials for cultivation with sulfate-reducing bacteria: fPE - foamed polyethylene, EVA - ethylene vinyl acetate; a - control (Postgate "B" nutrient medium without adding the bacteria), $b$ - after 30 days of exposure, $c$ - under the influence of bacteria during 90 days, $d$ - under the influence of bacteria during 90 days (the magnitude $x 14$ times)

\section{Table 1}

The change of the SRB cells amount during exposure with materials

\begin{tabular}{|l|l|c|c|c|c|}
\hline \multirow{2}{*}{$\begin{array}{l}\text { Material } \\
\text { sample }\end{array}$} & \multicolumn{1}{|c|}{ SRB strain } & \multirow{2}{*}{ Initial titer, cell/ml } & \multicolumn{3}{|c|}{ Final titer, cell/ml } \\
\cline { 4 - 6 } & & & $\mathbf{1 4}$ days & $\mathbf{3 0}$ days & $\mathbf{9 0 ~ d a y s ~}$ \\
\hline \multirow{4}{*}{ Control } & Desulfovibrio sp.10 & $1.0 \times 10^{6}$ & $1.0 \times 10^{9}$ & $1.0 \times 10^{10}$ & $1.0 \times 10^{10}$ \\
\cline { 2 - 6 } & D. desulfuricans DSM642 & $4.0 \times 10^{6}$ & $1.5 \times 10^{9}$ & $1.0 \times 10^{10}$ & $1.0 \times 10^{10}$ \\
\cline { 2 - 6 } & D. vulgaris DSM644 & $3.6 \times 10^{7}$ & $1.5 \times 10^{9}$ & $1.0 \times 10^{10}$ & $1.0 \times 10^{10}$ \\
\hline \multirow{4}{*}{ Rubber } & Desulfovibrio sp. 10 & $3.5 \times 10^{7}$ & $1.5 \times 10^{9}$ & $1.0 \times 10^{10}$ & $1.0 \times 10^{10}$ \\
\cline { 2 - 6 } & D. desulfuricans DSM642 & $3.6 \times 10^{6}$ & $9.5 \times 10^{8}$ & $1.0 \times 10^{10}$ & $1.0 \times 10^{10}$ \\
\cline { 2 - 6 } & D. vulgaris DSM644 & $4.0 \times 10^{6}$ & $1.0 \times 10^{9}$ & $7.5 \times 10^{9}$ & $1.0 \times 10^{10}$ \\
\hline \multirow{3}{*}{ EVA } & Desulfovibrio sp. 10 & $3.5 \times 10^{7}$ & $4.5 \times 10^{8}$ & $1.0 \times 10^{9}$ & $1.0 \times 10^{10}$ \\
\cline { 2 - 6 } & D. desulfuricans DSM642 & $3.6 \times 10^{6}$ & $5.0 \times 10^{8}$ & $1.0 \times 10^{10}$ & $1.0 \times 10^{10}$ \\
\cline { 2 - 6 } & D. vulgaris DSM644 & $4.0 \times 10^{6}$ & $1.5 \times 10^{9}$ & $1.0 \times 10^{10}$ & $1.0 \times 10^{10}$ \\
\cline { 2 - 6 } & Desulfovibrio sp. 10 & $3.5 \times 10^{7}$ & $2.0 \times 10^{9}$ & $1.0 \times 10^{10}$ & $1.0 \times 10^{10}$ \\
\cline { 2 - 6 } & D. desulfuricans DSM642 & $3.6 \times 10^{6}$ & $4.5 \times 10^{9}$ & $1.0 \times 10^{10}$ & $1.0 \times 10^{10}$ \\
\cline { 2 - 6 } & D. vulgaris DSM644 & $4.0 \times 10^{6}$ & $4.5 \times 10^{9}$ & $1.0 \times 10^{10}$ & $1.0 \times 10^{10}$ \\
\hline
\end{tabular}

Legend: fPE - foamed polyethylene, EVA - ethylene vinyl acetate.

sterile Postgate "B" medium. This may indicate on the effect of hydration of material samples, or the phenomenon of fouling of porous materials with bacterial biomass.

We studied the metabolic activity of SRB in the presence of the studied materials, in particular, the enzymatic activity, the production of hydrogen sulphide and the synthesis of organic acids.

Microorganisms are synthesizing a significant number of enzymes, in particular red-ox enzymes, which catalyze redox processes that occur in bacterial cells. Due to catalase, the decomposition of hydrogen peroxide occurs, as well as the oxidation of hydroxyl groups of polymers. In the 
Table 2

The destruction coefficient of rubber and polymer materials under the SRB influence

\begin{tabular}{|l|c|c|c|c|}
\hline \multirow{3}{*}{$\begin{array}{l}\text { Materials } \\
\text { sample }\end{array}$} & \multirow{2}{*}{ SRB strain } & \multicolumn{2}{|c|}{ The destruction coefficient, \% } \\
\cline { 2 - 5 } & control* & 14 days & 30 days & 90 days \\
\hline \multirow{4}{*}{ Rubber } & Desulfovibrio sp. 10 & $0 * *$ & 0 & 0 \\
\cline { 2 - 5 } & D. desulfuricans DSM642 & 0 & 0 & 2.33 \\
\cline { 2 - 5 } & D. vulgaris DSM644 & 1.20 & 0 & 0 \\
\hline \multirow{4}{*}{ fPE } & control & 1.05 & 0.78 & 2.99 \\
\cline { 2 - 5 } & Desulfovibrio sp. 10 & 0 & 1.00 & 1.03 \\
\cline { 2 - 5 } & D. desulfuricans DSM642 & 0 & 1.50 & 0.57 \\
\cline { 2 - 5 } & D. vulgaris DSM644 & 0 & 0.97 & 2.88 \\
\cline { 2 - 5 } & control & 0 & 0 & 0.17 \\
\cline { 2 - 5 } & Desulfovibrio sp. 10 & 0 & 0 & 0.57 \\
\cline { 2 - 5 } & D. desulfuricans DSM642 & 0 & 0 & 0.38 \\
\hline
\end{tabular}

Legend: * control - Postgate "B" medium without lactate and adding of SRB, ** 0 - there was no decrease in the mass of the polymer sample during the exposure, fPE - foamed polyethylene, EVA - ethylene vinyl acetate.

studies of the enzymatic activity of SRB in the presence of polymers, as the sole source of carbon, it was observed the decreasing in catalase activity in cultural liquids with the introduction of rubber by 1.6-1.9 times, EVA - by 1.4-3.4 times and
fPE - by 2.2-3.1 times, compared to the control variants (Fig. 2). It should be noted that the catalase activity of bacteria increased as the exposure time of polymers with SRB passed. In the control variants without adding polymers on the $14^{\text {th }}$ day,
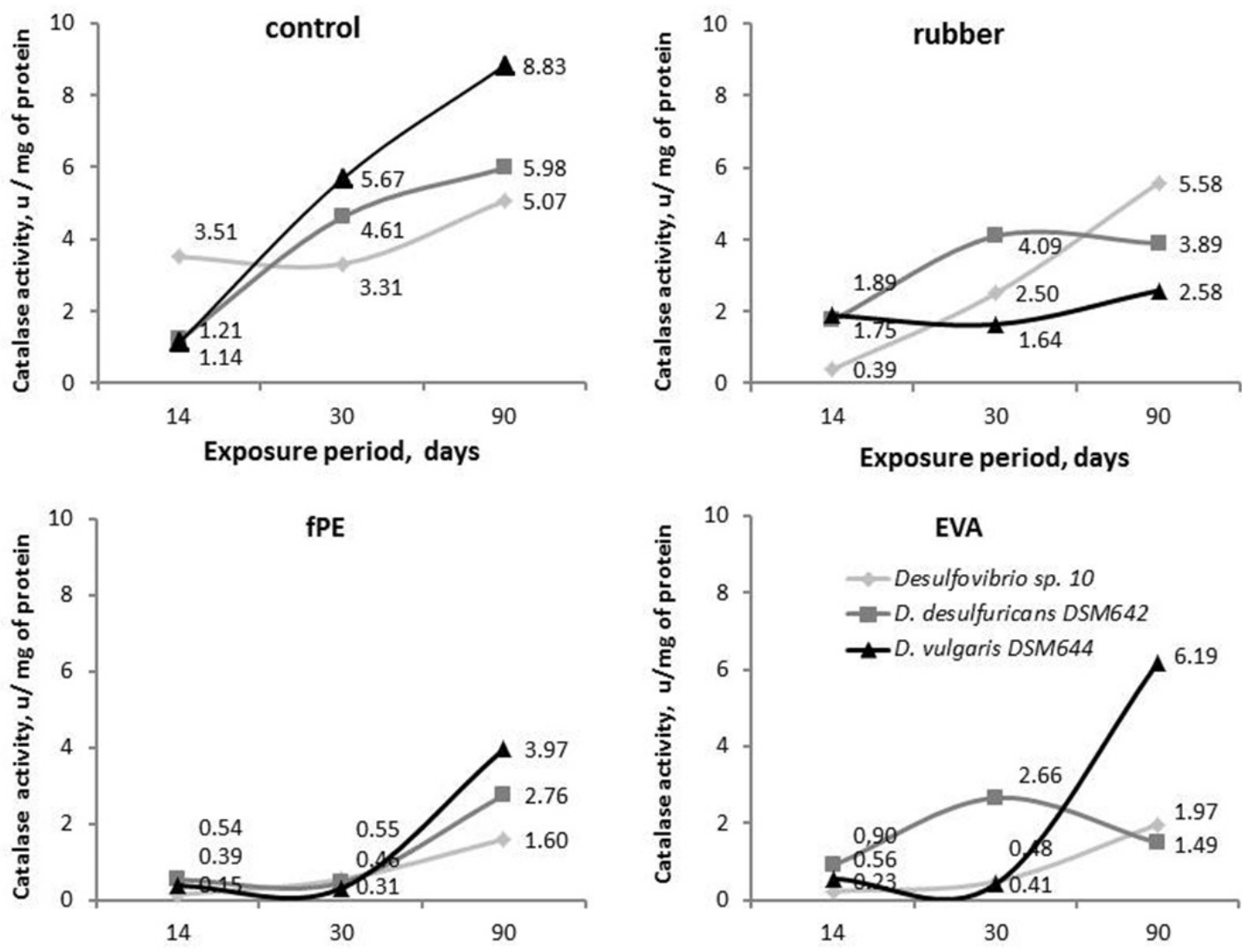

Exposure period, days

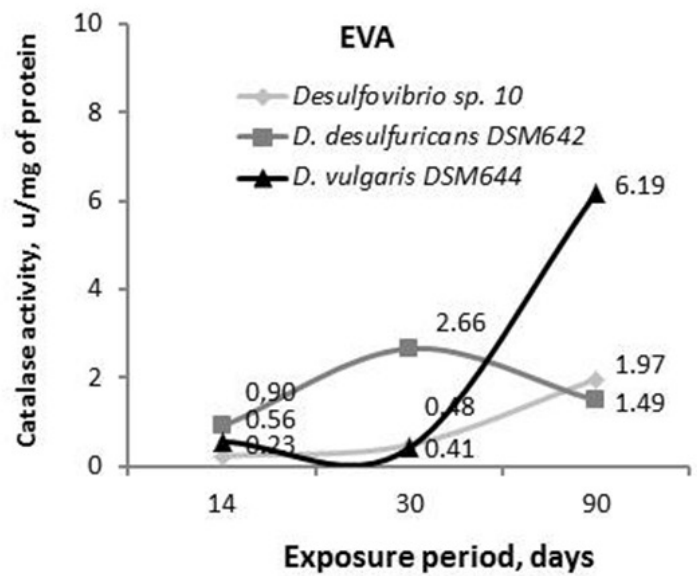

F i g. 2. Catalase activity of sulfate-reducing bacteria in the presence of rubber and polymer materials: control - culture medium without polymer application; fPE - foamed polyethylene; EVA - ethylene vinyl acetate 
the catalase activity of SRB was 1.14-3.51 units/ $\mathrm{mg}$ of protein, and on the $90^{\text {th }}$ day it increased up to $5.07-8.83$ units/mg of protein.

On the $14^{\text {th }}$ day of exposition, the catalase activity of cultural liquid with the introduction of rubber was $0.39-1.89$ units $/ \mathrm{mg}$ of protein and increased on the $90^{\text {th }}$ day up to $2.58-5.58$ unit $/ \mathrm{mg}$ of protein, respectively and for PPE - from $0.15-0.54$ to $1.6-3.97 \mathrm{unit} / \mathrm{mg}$ of protein, and for EVA from $0.23-0.90$ to $1.49-6.19 \mathrm{unit} / \mathrm{mg}$ of protein. Among the studied SRB strains, high catalase activity for D. vulgaris DSM644 was noted both in the control variant (8.83 unit/mg of protein) and with samples of EVA and fPE (6.19 and 3.97 unit/mg of protein, respectively). Consequently, the introduction of the
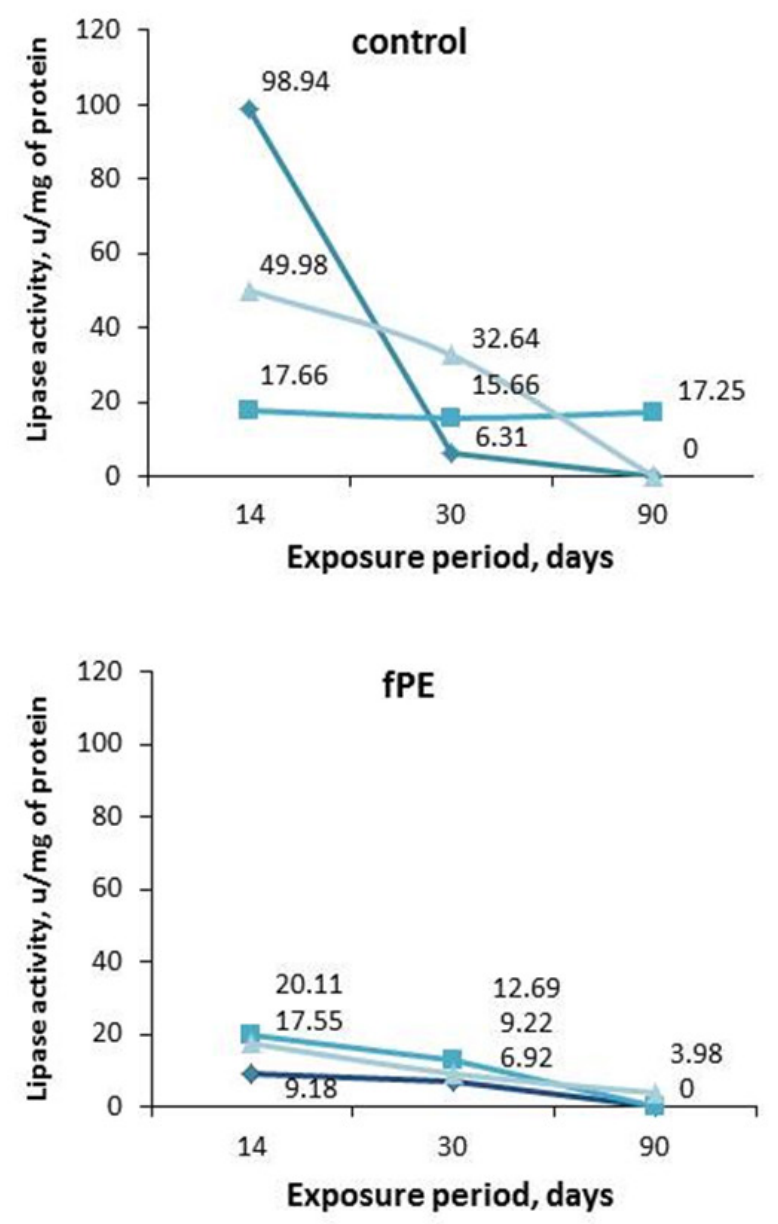

studied materials caused the decreasing catalase activity in the cultural liquids of SRB, compared to the controls. However, catalase activity increased with exposition of polymers with SRB. After rubber adding to the media, the catalase activity of SRB increased by $26.7-93 \%$, EVA - by 39.6-91\%, and fPE - by $80.4-90.6 \%$, respectively, compared to the beginning of the exposure (14 days).

Polymer materials contain significant amounts of hydrophobic components that can contribute to the activity of lipases - enzymes that catalyze the hydrolysis of insoluble esters - lipid substrates.

In studies of the lipolytic activity of SRB, in the presence of polymers as the sole sources of carbon, significant changes were found (Fig. 3).
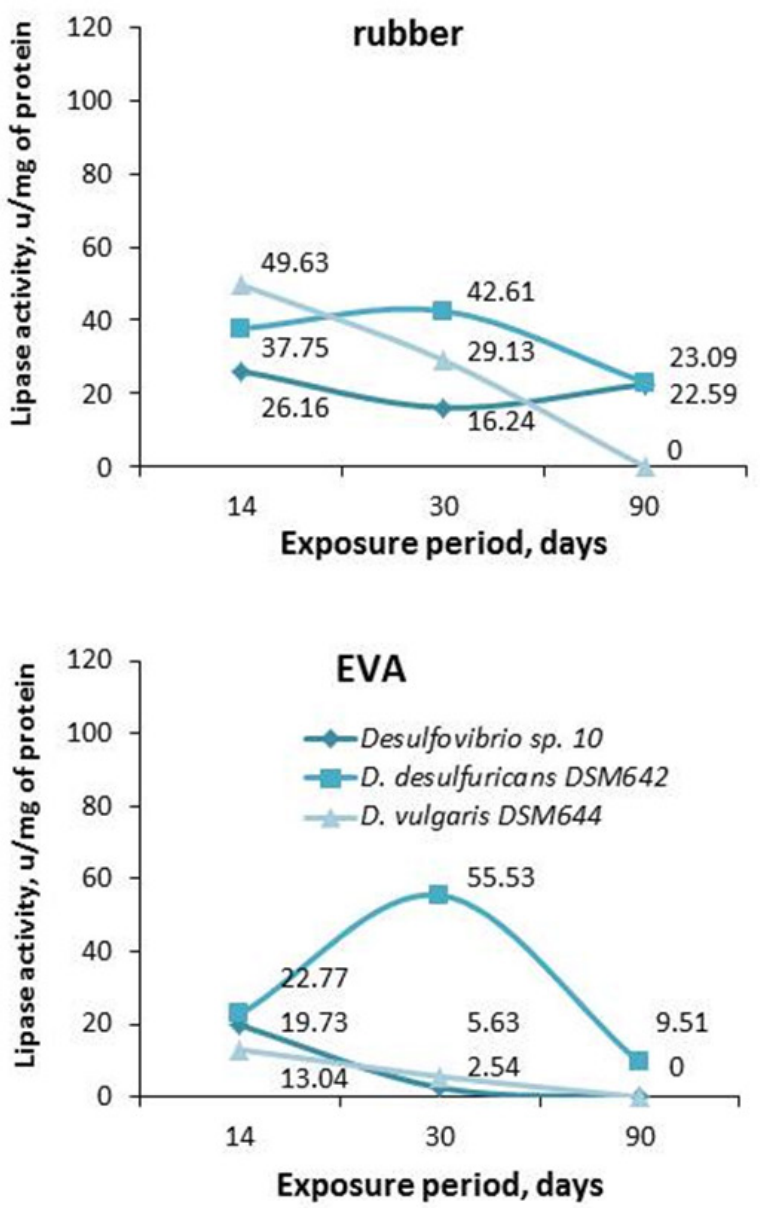

F i g. 3. Lipolytic activity of SRB in the presence of rubber and polymer materials: control nutrient medium without adding the materials; $\mathrm{PPE}$ - foamed polyethylene;

EVA - ethylene vinyl acetate

Lipase activity in the control on the $14^{\text {th }}$ day of exposure was 17.66-98.94 units/mg of protein, on the $30^{\text {th }}$ day decreased to 6.31-32.64 units/ $\mathrm{mg}$ of protein, and on the $90^{\text {th }}$ day lipase activity was measured only for $D$. desulfuricans DSM642 (17.25 units/mg of protein). For all other SRB strains it disappeared.
In the variants with rubber, the lipase activity of SRB on the $14^{\text {th }}$ day was $26.16-49.63$ units $/ \mathrm{mg}$ of protein and on the $90^{\text {th }}$ day it decreased to the values of 22.59-23.09 units/mg of protein. There was no lipase activity in D. vulgaris DSM644. For the introduction of fPE, the lipase activity of SRB on the $14^{\text {th }}$ day was $2.03-20.11$ units $/ \mathrm{mg}$ of 
protein and on the $90^{\text {th }}$ day, the lipase activity was absent in the variants with Desulfovibrio sp. 10 and D. desulfuricans DSM642. After exposure with EVA, lipase activity on the $14^{\text {th }}$ and $90^{\text {th }}$ day was $13.04-22.77$ unit $/ \mathrm{mg}$ of protein and up to 6.19 units $/ \mathrm{mg}$ of protein, respectively, and was found only in $D$. desulfuricans DSM642 strain.

Consequently, the decreasing in the catalase activity of SRB (in comparison with the control) was observed. The lipase activity of SRB cultures due to the introduction of various polymers with the duration of exposure decreased and in some cases almost disappeared, but compared to the control without materials, a slight increase in the lipolytic activity of SRB was detected.

Subsequently, the influence of polymer materials on the metabolic activity of SRB was evaluated; in particular, changes in the $\mathrm{pH}$ of the medium and the production of hydrogen sulphide by bacterial strains were determined. It was found that the $\mathrm{pH}$ of the cultural liquid of all three SRB strains without adding the polymers was neutral in range 7.06-7.38 (Fig. 4). When adding rubber, the $\mathrm{pH}$ of cultural liquid increased to 7.30-8.54, and in the presence of $\mathrm{PPE}$ and EVA, the medium was acidified to $6.05-7.25$ and 6.30-6.66, respectively. There was a slight leaching of the cultural liquids of $D$. desulfuricans DSM642 (up to $\mathrm{pH} 7.94$ ) due to the introduction of EVA and Desulfovibrio sp. 10 (to $\mathrm{pH} 8.38$ ) in the presence of fPE.

In the control variant without the introduction of materials, on the $14^{\text {th }}$ day of exposition hydrogen sulphide production by SRB was $63.7-68.0 \mathrm{mg} / \mathrm{l}$. On the $30^{\text {th }}$ day SRB produced the hydrogen sulphide at concentration of $136.0-164.3 \mathrm{mg} / \mathrm{l}$, then on the $90^{\text {th }}$ day decreased to $20.4-119.0 \mathrm{mg} / 1$. For the introduction of EVA, the highest levels of hydrogen sulphide synthesis by SRB (226.6$464.6 \mathrm{mg} / \mathrm{l})$ were noted on the $30^{\text {th }}$ day, which exceeded the control values by 1.7-3.0 times. In the presence of fPE, the amount of hydrogen sulphide in the cultural liquid was $0.8-2.2$ times higher than in the control. When adding rubber, the production of $\mathrm{H}_{2} \mathrm{~S}$ by $\mathrm{SRB}$ was decreased by $1.2-$
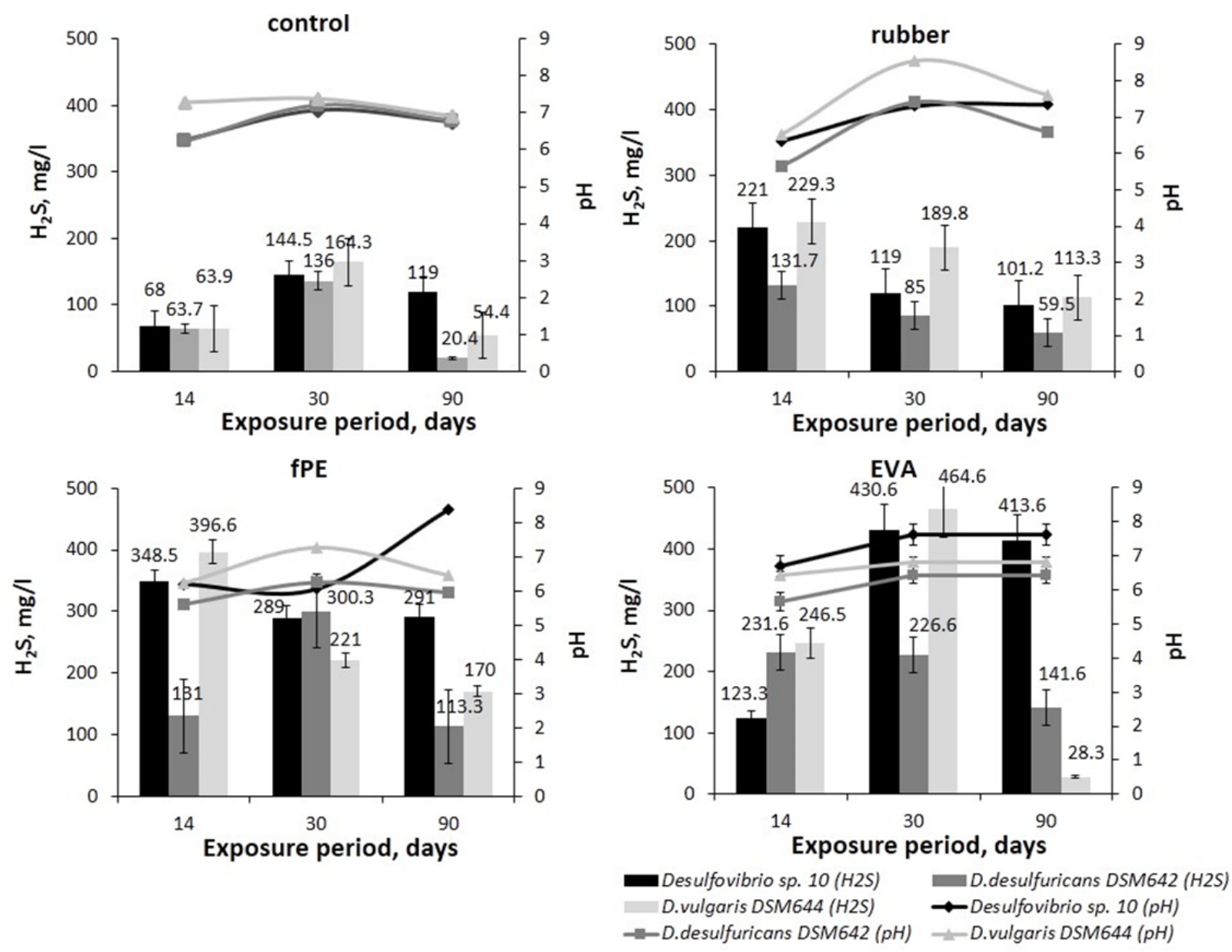

F i g. 4. Dynamics of hydrogen sulfide production and changes in the $\mathrm{pH}$ of cultural liquid during cultivation of sulfate-reducing bacteria with rubber and polymer materials: control - nutrient medium without adding the materials; fPE - foamed polyethylene; EVA - ethylene vinyl acetate 
3.5 times. With increased production of $\mathrm{H}_{2} \mathrm{~S}$, the $\mathrm{pH}$ of the cultural liquid decreased, which indicates an inverse relationship of these indicators. Thus, the introduction of polymeric materials affects the process of sulfate reduction in SRB, in most cases, intensified the synthesis of hydrogen sulphide, however, with increasing exposure period up to 90th days the production of hydrogen sulphide significantly decreased, which may be associated with slower growth of SRB and the exhaustion of the cultural liquid on the available sulfates, cause sulfur-containing compounds in polymers (e.g. rubber) were not available for SRB.

One of the important indicators of the metabolic activity of SRB during polymer biodegradation is the production of short-chain fatty acids, which can be involved in the mechanisms
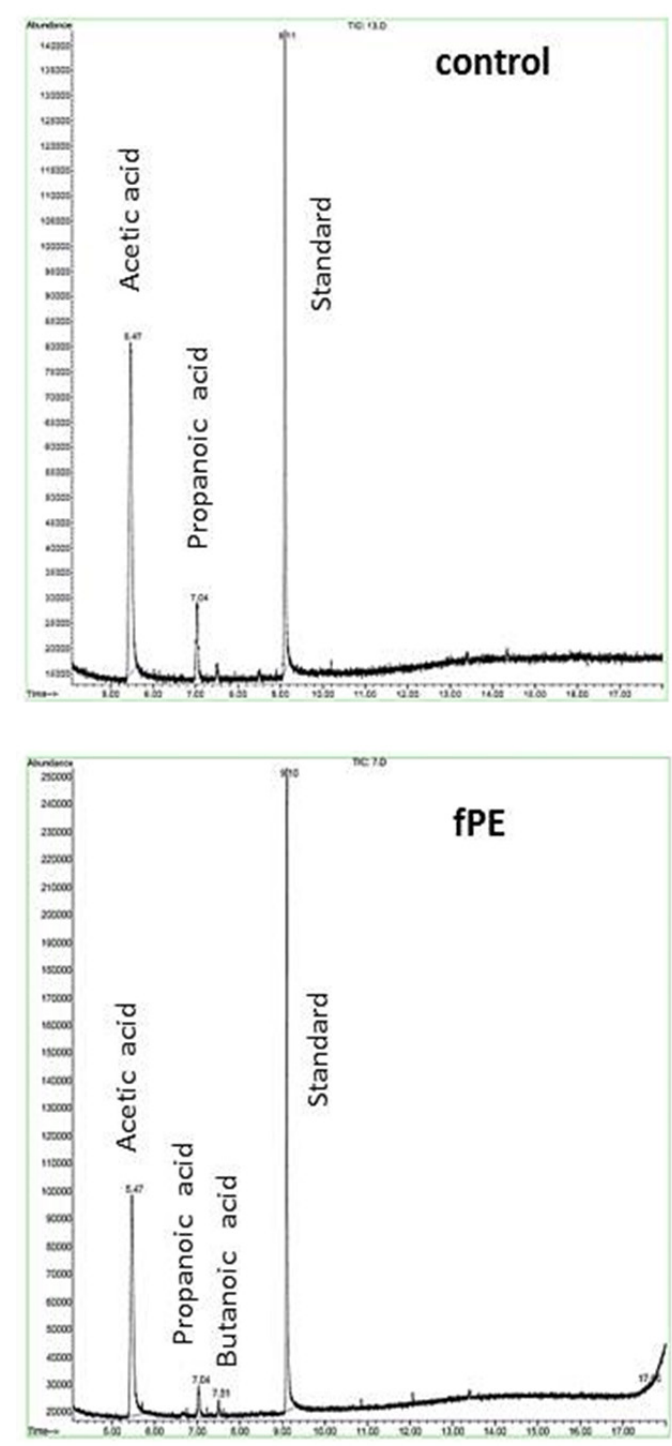

of polymer biodegradation. Acetic and propanoic acid were detected in the bacterial culture liquid without the addition of polymers in the amounts of $31.71-44.17 \mu \mathrm{g} / \mathrm{ml}$ and $4.84-7.71 \mu \mathrm{g} / \mathrm{ml}$, respectively, butanoic acid was not detected (Fig. 5, Table 3).

In the experimental variants with the addition of materials, the content of short-chain fatty acids varied depending on the bacterial culture and was $29.80-53.52 \mu \mathrm{g} / \mathrm{ml}$ and $0-6.70 \mu \mathrm{g} / \mathrm{ml}$ of acetic and propanoic acids, respectively.

During the introduction of rubber to the cultural liquid of D. vulgaris DSM644 an increase in the content of acetic and propanoic acids by 59 and $49.5 \%$, respectively was showed. While in the cultural liquids of other bacterial strains, the content of acetic and propanoic acids decreased by $4.9-32.5$
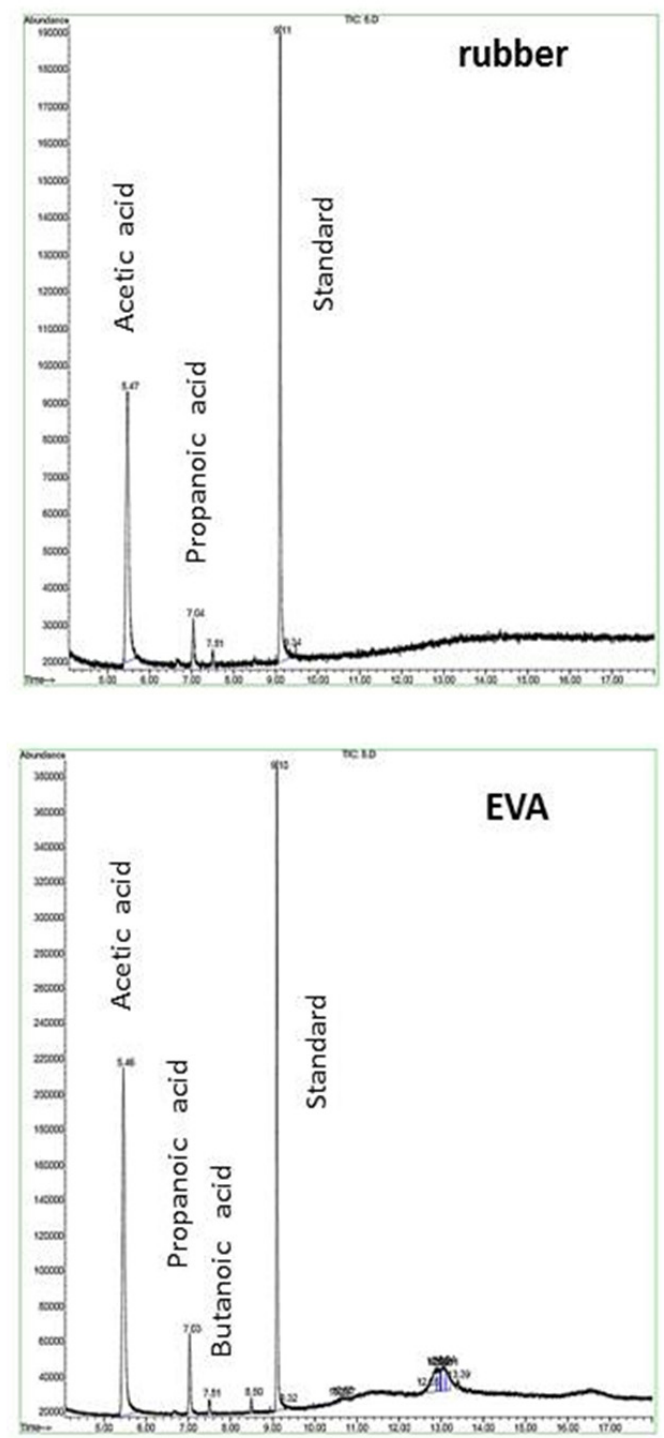

F i g. 5. Chromatograms of short-chain fatty acids in the cultural liquid of $D$. desulfuricans DSM642 (UCM B-11501) without and with adding the polymers: control - cultural liquid of SRB without materials; fPE - foamed polyethylene; EVA - ethylene vinyl acetate; standard isovaleric (30-methylbutanoic) acid in the final concentration of $40 \mu \mathrm{g} / \mathrm{ml}$ 
and $45.1 \%$, respectively, compared to the control. No butanoic acid was found in the supernatant of cultural liquid when the rubber was added. With the introduction of fPE in the cultural liquids of D. vulgaris DSM644 and D. desulfuricans DSM642, the content of acetic and propanoic acids increased by 419.5 and $276 \%$ as well by 46.2 and $23.1 \%$, respectively. The appearance of butanoic acid in the cultural liquids of these two SRB strains in the amount of 1.06 and $6.26 \mu \mathrm{g} / \mathrm{ml}$ was noted. In the cultural liquid of Desulfovibrio sp. 10 the acid content decreased by $29.2 \%$ and $68.4 \%$, respectively. When EVA was added to the nutrient medium with SRB, the content of organic acids in D. desulfuricans DSM642 and D. vulgaris DSM644 increased by 69.8-92.6\% and 71.9$159 \%$, respectively. Acetic and propanoic acid content in Desulfovibrio sp. 10 cultural liquid decreased by 16.1 and $48.9 \%$. Butanoic acid (in concentration $1.32 \mu \mathrm{g} / \mathrm{ml}$ ) was found only in $D$. desulfuricans DSM642 strain.

Therefore, the intensification of acid formation refers to an increase in the metabolic activity of SRB and confirms the fact that one of the mechanisms of polymer biodegradation under anaerobic conditions is the synthesis of inorganic and organic acids that affect polymers destroying them.

\section{Table 3}

The content of short-chain fatty acids in the cultural liquid of SRB at the introduction of the studied polymer compounds, $\mu \mathrm{g} / \mathrm{ml}$

\begin{tabular}{|c|c|c|c|}
\hline Variant of experiment & Acetic acid & Propanoic acid & Butanoic acid \\
\hline \multicolumn{4}{|c|}{ Control (without adding polymer) } \\
\hline Desulfovibrio sp. 10 & 44.17 & 7.71 & 0 \\
\hline D. desulfuricans DSM642 & 31.71 & 5.32 & 0 \\
\hline D. vulgaris DSM644 & 33.46 & 4.84 & 0 \\
\hline \multicolumn{4}{|c|}{ Rubber } \\
\hline Desulfovibriosp. 10 & 29.80 & 0 & 0 \\
\hline D. desulfuricans DSM642 & 30.15 & 2.92 & 0 \\
\hline D. vulgaris DSM644 & 53.52 & 6.70 & 0 \\
\hline \multicolumn{4}{|c|}{ fPE } \\
\hline Desulfovibrio sp. 10 & 31.24 & 2.43 & 0 \\
\hline D. desulfuricans DSM642 & 46.37 & 6.55 & 1.06 \\
\hline D. vulgaris DSM644 & 173.85 & 18.20 & 6.26 \\
\hline \multicolumn{4}{|c|}{ EVA } \\
\hline Desulfovibrio sp. 10 & 37.06 & 3.94 & 0 \\
\hline D. desulfuricans DSM642 & 53.85 & 9.15 & 1.32 \\
\hline D. vulgaris DSM644 & 64.46 & 12.54 & 0 \\
\hline
\end{tabular}

Discussion. Assessment of the degree of biodegradation of materials during 90 days indicates low percentages of destruction coefficients $\left(\mathrm{K}_{\mathrm{D}}=0-1.07 \%\right)$. However, these substrates were still subjected to the destructive effect of SRB, which was manifested in surface deformation, loss and color change. Authors [18] had indicated similar changes in samples of polymer materials under the influence of SRB, namely, wrinkling of samples, the appearance of plaque (in particular, black). These changes in the morphology of the studied materials do not confirm the presence of biodegradation, but may act as the first sign of microbial effects on polymers. In addition, the high final titers of SRB indicates on the ability of bacteria to grow in the presence of rubber and polymer materials, using them as the sole source of carbon, while polymers do not have an inhibitory effect on bacteria.

The weight loss of the studied polymeric and rubber samples under the influence of collection SRB cultures in our studies was insignificant. Although it was reported that Bacillus strains isolated from contaminated soil and wastewater from oil production plants could degrade polyacrylamide (PAM) by $36.3 \%$ of the initial mass [19], as well as SRB in activated sludge improved its biodegradation up to $61.2 \%$ [20]. During anaerobic decomposition of PAM in dehydrated activated sludge, it was shown that biodegradation reached up to $86.4 \%$ (under $\mathrm{pH}$ 9.0). However, it should be noted that such high indicators were obtained for associations and microbial communities of wastewaters, where a 
synergistic effect is observed [21].

As for the decomposition of rubber, it is now known about the ability of separate cultures of D. vulgaris to utilize carbon tetrachloride (as one of the components in the production of rubber), the degree of destruction of this material was 13$65 \%$ for 12 days of cultivation [22]. The ability of SRB to utilize polyvinyl chloride was reported, the highest degree of its utilization was 17.9-63.8\% during 21 days of cultivation [23].

The studied materials affected on such indicators of the metabolic activity of SRB as production of hydrogen sulfide, changes in the $\mathrm{pH}$ of the cultural liquid, enzymatic activity, and synthesis of organic acids. Changes in the $\mathrm{pH}$ of the cultural liquid can occur as a result of the release of both biogenic hydrogen sulfide and acidic products from polymers as a result of their biodegradation due to the influence of bacterial enzyme systems. In addition, studies of many foreign scientists have revealed that a number of lipases, esterases, cutinases and other enzymes hydrolyze polyethylene terephthalate (PET) and modify the surface of PET films [24]. In the work [25], the ability of $B$. subtilis strain to degrade natural rubber by $48.6 \%$ was found. It is known that microorganisms adapting to the environment can synthesize both endo- and exoenzymes [4]. Extracellular enzymes (exoenzymes) released by microorganisms can catalyze polymer breakdown reactions into smaller fragments, thereby destroying them [26]. Enzymes that are secreted by microorganisms convert polymers into monomers, and these monomers are then absorbed by the microbes' permeating membranes and once in the cells are involved in the development of metabolic pathways for energy and/or serve as building blocks for catabolism or anabolism.

It is known about the ability of SRB of Desulfovibrio, Desulfobacter and Desulfotomaculum genera to release organic acids (acetate, propionate, butyrate, etc.) as metabolic products during the biodegradation of polymer compounds [27]. Due to acid formation, the $\mathrm{pH}$ inside the polymer bubbles changes, which leads to gradual degradation, which changes the microstructure of the plastic matrix [26]. Our results allow us to conclude that in the process of degradation, microorganisms release organic and inorganic acids into the medium, which contribute to changes in the acidity of the medium and the destruction of the studied samples due to acid formation. The increase in acid synthesis did not occur for all SRB strains, in particular, for the Desulfovibrio sp. 10 strain the amount of synthesized acetic and propanoic acids was decreased. We could explain this fact that SRB can use organic acids and alcohols as a nutrient source [28]. For bacteria with incomplete substrate oxidation, in particular in some members of the Desulfovibrio genus, the end product is acetate [29].

Generally, an increase in the synthesis of acids and hydrogen sulfide during the introduction of the studied materials indicates an increase in the metabolic activity of SRB and confirms the fact that one of the mechanisms of polymer biodegradation under anaerobic conditions is the direct action of acids synthesized by anaerobic bacteria that contact with polymers and destroy them. So, one of the mechanisms of polymer destruction due to the action of SRB is acid formation.

Conclusions. During the cultivation of the sulfate-reducing bacteria with rubber, foamed polyethylene or ethylene vinyl acetate as the sole sources of carbon, changes occurred both in the metabolic activity of bacteria and in the morphology of materials. On the $90^{\text {th }}$ day of the experiment the destruction coefficients of the studied materials were low and reached up to $0.21-2.88 \%$. The amount of sulfate-reducing bacteria increased by $2-3$ orders compared with the control without adding the materials. Catalase activity decreased by $1.4-3.4$ times and lipolytic activity decreased by 1.6-5.8 times. In the presence of foamed polyethylene and ethylene vinyl acetate the synthesis of acetic acid increased by $46.2-$ $419.5 \%$ and $69.8-92.6 \%$, propanoic - by $23.1-$ 46.2 and $71.9-159.0 \%$, respectively. The obtained data indicates the potential ability of sulfatereducing bacteria to utilize studied polymeric and rubber materials via acid formation. 


\section{ЗДАТНІСТЬ СУЛЬФАТВІДНОВЛЮ- ВАЛЬНИХ БАКТЕРІЙ ДО УТИЛІЗАЦІЇ ПОЛІМЕРНИХ І ГУМОТЕХНІЧНИХ МАТЕРІАЛІВ}

\section{Д.Р. Абдуліна ${ }^{1}$, А.І. Чуєнко ${ }^{1}$, А.С. Топчій², Г.Е. Коптева ${ }^{1}$ Ж.П. Коптева ${ }^{1}$}

${ }^{1}$ Інститут мікробіології і вірусології ім. Д.К. Заболотного НАН України, вул. Академіка Заболотного, 154, Київ, 03143, Україна,

${ }^{2}$ Київський національний університет імені Тараса Шевченка, просп. Академіка

Глушкова, 2, Київ, 02000, Украӥна

\section{Резюме}

Полімерні матеріали є невід'ємною частиною нашого життя, однак їх використання є глобальною екологічною проблемою. Зважаючи на це, в наш час актуальною $є$ розробка сучасних підходів утилізації відпрацьованих полімерних та гумотехнічних матеріалів, у тому числі за використання анаеробної мікробної деструкції полімерів сульфатвідновлювальними бактеріями. Мета. Дослідити здатність сульфатвідновлювальних бактерій до утилізації гумотехнічних та полімерних матеріалів - суцільнолитої гуми, етиленвінілацетату та пінополіетилену. Методи. Мікробіологічні (культивування сульфатвідновлювальних бактерій, метод граничних розведень), біохімічні (метод Лоурі, визначення ферментативної активності), фізикохімічні (гравіметрія, йодометрія, потенціометрія, газова хромато-мас-спектрометрія). Результати. Показано, що у присутності досліджуваних матеріалів як єдиних джерел карбону кількість сульфатвідновлювальних бактерій зростала на 2-3 порядки порівняно з контролем без внесення матеріалів. Коефіцієнти деструкції $\mathrm{K}_{\mathrm{D}}$ досліджуваних матеріалів були невисокими і на 90-ту добу експерименту сягали 0,21-2,88 \%. За внесення в поживне середовище досліджуваних матеріалів змінювалась метаболічна та ферментативна ак-

1. Assoc. Plast. Manuf. Eur. (APME). An Analysis of Plastics Production, Demand and Recovery in Europe. 2006.

2. North E, Halden R. Plastics and Environmental Health: The Road Ahead. Rev Environ Health. 2013; 28 (1):1-8.

3. Chuenko AI, Subbota AG, Olishevska SV, Zaslavsky VA, Zhdanova NM. [Contamination of unit cast rubber tyres by microscopis fungi]. тивності сульфатвідновлювальних бактерій, зокрема, продукування сірководню за присутності етиленвінілацетату і пінополіетилену збільшувалось у $0,8-3,0$ рази, а гуми - знижувалось у $1,2-$ 3,5 рази. Каталазна активність досліджуваних культур бактерій знижувалась у 1,4-3,4 рази порівняно 3 контролем, без внесення матеріалів. Ліполітична активність культур сульфатвідновлювальних бактерій за внесення різних полімерів із тривалістю експозиції спадала і у деяких випадках майже зникала. Внесення матеріалів спричиняло підвищення синтезу коротколанцюгових жирних кислот штамами Desulfovibrio desulfuricans DSM642 та D. vulgaris DSM644, a штам Desulfovibrio sp. 10, навпаки, показав зниження продукування кислот. За внесення гуми лише у культури $D$. vulgaris DSM644 підвищувався синтез оцтової та пропанової кислот на $59 \%$ та 49,5 \% відповідно, порівняно з контролем, без внесення досліджуваних матеріалів. Синтез оцтової кислоти за присутності пінополіетилену і етиленвінілацетату у культуральній рідині сульфатвідновлювальних бактерій зростав на 46,2$419,5 \%$ та 69,8-92,6 \%, а пропанової - на 23,146,2 та 71,9-159,0 \% відповідно. Висновки. Присутність у середовищі пінополіетилену, етиленвінілацетату та гуми як єдиних джерел карбону викликали зміни у ферментативній активності (каталазній та ліпазній), інтенсифікувалося продукування сірководню сульфатвідновлювальними бактеріями та синтез оцтової, пропанової та бутанової кислот. Це свідчить про потенційну здатність сульфатвідновлювальних бактерій до утилізації досліджених матеріалів шляхом кислотоутворення.

Ключові слова: сульфатвідновлювальні бактеpiï, біодеградація, коефіцієнт деструкції, каталазна, ліпазна активності, коротколанцюгові жирні кислоти, полімерні та гумотехнічні матеріали.

Mikrobiol Z. 2010; 72(3):36-42. Ukrainian.

4. Albinas L, Loreta L, Dalia P. Micromycetes as deterioration agents of polymeric materials. International Biodeterioration and Biodegradation. 2003; 52:233-242.

5. Sazonova OI, Vetrova AA, Streletsky RA, Gafarov AB, Kosheleva IA, Filonov AE, Sokolov SL. [The Pseudomonas extrema ustralis 7-31 and Pseudomonas fluorescens 7-41, degrading 
aliphatic and aromatic hydrocarbons]. Izv. Tuls. Gos. Univ. Estetst Nauk. 2019; 3:31-43. Russian.

6. Kobrina LV, Boiko VV, Dmytriieva TV ta in. [Vplyv fizychnykh chynnykiv i kultur mikroorhanizmiv na dehradatsiiu sehmentovanoho poliuretanu]. Polimer. Z. 2016; 38(3):236-243. Ukrainian.

7. Andler R, Hiessl S, Yücel O, Tesch M, Steinbüchel A. Cleavage of poly (cis-1,4-isoprene) rubber as solid substrate by cultures of Gordonia polyisoprenivorans. N. Biotechnol. 2018; 44:612.

8. Kopteva ZhP, Zanina VV, Boretskaya MA, Kopteva AE, Kozlova IA. [Effect of lipolytic and catalase activity of heterotrophic bacteria on physico-mechanical properties of coating Poliken 980-25]. Mikrobiol Z. 2013; 75(1):41-47. Russian.

9. Eskander S, Saleh H. Biodegradation: Process Mechanism. Environ Sci \&Engg. 2017; 8(1):131.

10. Yanovych DO, Yanovych NE. [Biotransformation of xenobiotics and mechanisms of its regulation]. Nauk. Vis. LNUVMBT im. S.Z. Gzhytskoho. 2011; 13(2):305-311. Ukrainian.

11. Yoshida S, Hiraga K, Takehana T, Taniguchi I, Yamaji H, Maeda Y, Oda K. A bacterium that degrades and assimilates poly (ethyleneterephthalate). Sci. 2016; 351 (6278):1196-99.

12. Abdulina DR, Kopteva ZhP, Kopteva AE, Vortman MYa. [Influence of polymeric and rubber materials on hydrocarbon-oxidizing bacteria]. Mikrobiologiya i biotehnologiya. 2019; 2:51-64. Russian.

13. Lu J, Jin Q, He Y. Biodegradation of nonylphenol polyethoxylates under sulfate-reducing conditions. Sci Total Environ. 2008; 399 (1-3):121127.

14. Aizenberg VL, Karpel VI, Syrchin SA, Sedina SA, Kapichon AP. [Testing a quantitative method for determining lipolytic activity using a chromogenic substrate]. Mikrobiol Z. 1995; 57 (5):84-89. Russian.

15. Korolyuk MA, Ivanova LI, Mayorov IG, Tokarev VE. [Method for the determination of catalase activity. Laboratory work]. 1988; 1:16-18. Russian.
16. ISO 846:2019. Plastics - Evaluation of the action of microorganisms. Pub Date 03.2019; 26.

17. Baumann I, Westermann P. Microbial production of short chain fatty acids from lignocellulosic biomass: current processes and market. BioMed Research International. 2016; 3(20):1-15.

18. Morales S, Balagurusamy N, Herrera R. Anaerobic biodegradation of polyaromatic hydrocarbons by a sulfate reducing bacteria C1Fd Strain. JPAM. 2017; 11(2):793-801.

19. Bao M, Chen Q, Li Y. Biodegradation of partially hydrolyzed polyacrylamide by bacteria isolated from production water after polymer flooding in an oil field. J Hazard Mater. 2010; 184:105-110.

20. Ma F, Wei L, Wang L, Chang C. Isolation and identification of the sulphate reducing bacteria strain $\mathrm{H} 1$ and its function for hydrolysed polyacrylamide degradation. Int J Biotechnol. 2008; 10:55-63.

21. Dai X, Luo F, Zhang D, Dai L, Chen Y, Dong B. Waste-activated sludge fermentation for polyacrylamide biodegradation improved by anaerobic hydrolysis and key microorganisms involved in biological polyacrylamide removal. Sci Rep. 2015; 5(1):1-13.

22. Koenig C, Lee J, Manefield M. Successful microcosm demonstration of a strategy for biodegradation of a mixture of carbon tetrachloride and perchloroethene harnessing sulfate reducing and dehalorespiring bacteria. J Hazard Mat. 2012; 219-220:169-175.

23. Tsuchida D, Kajihara Y, Shimidzu N. Hydrogen sulfide production by sulfate-reducing bacteria utilizing additives eluted from plastic resins. Waste Management and Research. 2015; 29(6):594-601.

24. Zimmermann W, Billig S. Enzymes for the biofunctionalization of poly(ethylene terephthalate). Adv Biochem Eng Biot. 2011; 125:97-120.

25. Nayanashree G, Thippeswamy B. Biodegradation of natural rubber by laccase and manganese peroxidase enzyme of Bacillus subtilis. Environ Process. 2015; 2:761-772.

26. Bhardwaj H, Gupta R, Tiwari A. Microbial population associated with plastic degradation. Scientific Reports. 2012; 1(5):1-4. 
27. Muthukumar A, Veerappapillai S. Biodegradation of Plastics - A Brief Review. International Journal of Pharmaceutical Sciences Review and Research. 2015; 31(2):204-209.

28. Barton LL, Hamilton WA. Sulphate-Reducing Bacteria. Environmental and Engineered Systems. 2010. Cambridge University Press, 553.
29. Brahmacharimayum B, Mohanty P, Ghosh P. Theoretical and practical aspects of biological sulfate reduction: a review. Global NEST Journal. $2019 ; 21(2): 222-244$.

Received 17.12.2020 